\title{
PENGARUH MODEL PEMBELAJARAN PROBLEM BASED LEARNING TERHADAP HASIL BELAJAR PESERTA DIDIK SDN 008 CAMBA-CAMBA KABUPATEN POLEWALI MANDAR
}

\section{THE EFFECT OF PROBLEM BASED LEARNINGMODEL ON LEARNING OUTCOMES OF STUDENTS IN CLASS V SDN 008 CAMBA-CAMBA POLEWALI MANDAR REGENCY}

\author{
Munawir Anas ${ }^{1}$ \\ STAI DDI Majene, \\ Indonesia $^{1}$ \\ email: \\ anasmunawir86@gmail \\ .com
}

IJI Publication p-ISSN: 2774-1907 e-ISSN: 2774-1915 Vol. 1, No. 3, pp.163174, Juli 2021

Unit Publikasi Ilmiah Intelektual Madani Indonesia
Abstrak: Penelitian ini adalah penelitian kuantitatif dengan metode pre-experimental designs yang bertujuan untuk mengetahui ada tidaknya pengaruh penerapan model pembelajaran problem based learning terhadap hasil belajar matematika peserta didik kelas V SDN 008 Camba-camba Kabupaten Polewali Mandar. Variabel bebas dalam penelitian ini adalah penerapan model model pembelajaran problem based learning dan variabel terikatnya adalah hasil belajar matematika. Populasi dalam penelitian ini adalah seluruh peserta didik kelas V SDN 008 Camba-camba Kabupaten Polewali Mandar dengan jumlah peserta didik 29 orang, seangkan sampelnya adalah seluruh jumlah populasi yang berjumlah 29 orang peserta didik. Data hasil penelitian diperoleh dengan menggunakan lembar observasi dan tes hasil belajar matematika berupa pretest dan posttest. Data tersebut dianalisis dengan dua macam teknik analisis statistik, yaitu analisis deskriptif dan analisis infrensial dengan menggunakan program SPSS windows versi 23. Hasil penelitian menunjukkan bahwa kegiatan pembelajaran di kelas peserta didik terlihat aktif, kreatif, terfokus dan bersemangat dalam belajar. Hasil tes pretes dan posttes menunjukkan adanya peningkatan rata-rata hasil belajar siswa. Rata-rata hasil belajar pretest yaitu 38,60 berada pada rentang kategori rendah, sedangkan pada ratarata hasil belajar posttest yaitu 71,60 pada rentang kategori tinggi. Hasil analisis inferensial yaitu menggunakan uji-t paired sample test diperoleh data Sig. $<\alpha=0.05$ $(0.00<\alpha=0.05)$ artinya $\mathrm{H}_{0}$ Ditolak. Hal ini dapat disimpulkan bahwa terdapat pengaruh penerapan model pembelajaran problem based learning terhadap hasil belajar matematika peserta didik kelas V SDN 008 Camba-camba Kabupaten Polewali Mandar.

Kata Kunci: Model Pembelajaran, Problem Based Learning, Hasil Belajar.

Abstract: This research is a quantitative study with pre-experimental designs method that aims to determine whether there is an influence of the application of the problem based learning model of learning outcomes in mathematics learning for students in grade V SDN 008 Camba-camba Polewali Mandar Regency. The independent variable in this study is the application of problem based learning models and the dependent variable is the result of learning mathematics. The population in this study were all students in class V SDN 008 Camba-camba Polewali Mandar Regency with a total of 29 students, while the sample was the entire population of 29 students. The research data were obtained using observation sheets and mathematics learning achievement tests in the form of pretest and posttest. The data were analyzed with two kinds of statistical analysis techniques, namely descriptive analysis and infrential analysis using SPSS windows version 23. The results showed that the learning activities in the class of students looked active, creative, focused and enthusiastic in learning. Pretest and posttest test results showed an increase in average student learning outcomes. The average pretest learning outcomes of 38.60 are in the range of low categories, while the average posttest learning outcomes are 71.60 in the range of high categories. Results of inferential analysis using paired sample t-test obtained by Sig. $<\alpha=0.05(0.00<\alpha=$ 0.05) means $H_{0}$ is rejected. It can be concluded that there is an effect of the application of the problem based learning model to the mathematics learning outcomes of students in class V SDN 008 Camba-camba Polewali Mandar Regency.

Keywords: Learning Model, Problem Based Learning, Learning Outcomes.

\section{PENDAHULUAN}

Belajar merupakan unsur yang sangat mendasar dalam penyelenggaraan di semua jenjang pendidikan. Keberhasilan pencapaian tujuan pendidikan bergantung pada keberhasilan suatu proses belajar yang dilaksanakan di sekolah dan dukungan lingkungan sekitarnya. Proses belajar dapat terjadi karena interaksi seseorang dengan lingkungannya yang akan menghasilkan suatu perubahan tingkah laku pada berbagai 
aspek, diantaranya pengetahuan, sikap, dan keterampilan.

Peningkatan kualitas pendidikan juga tidak terlepas dari seluruh komponen pendidikan yang terkait dalam proses pembelajaran, salah satu komponen yang dimaksud adalah guru. Guru sebagai ujung tombak dalam pelaksanaan pendidikan merupakan pihak yang sangat berpengaruh dalam proses pembelajaran. Kepiawaian dan kewibawaan guru sangat menentukan kelangsungan proses belajar mengajar di kelas ataupun efeknya di luar kelas. Guru harus membawa peserta didik kepada tujuan yang hendak dicapai. Ada beberapa hal yang dapat membentuk kewibawaan guru, antara lain adalah penguasaan materi, penerapan pembelajaran yang sesuai dengan situasi dan kondisi peserta didik, serta hubungan antara individu.

Pada masa sekarang ini manusia di hadapkan pada kemajuan ilmu pengetahuan dan teknolagi, dimana pada era yang penuh dengan persaingan ini, peningkatan kualitas Sumber Daya Manusia (SDM). terutama peningkatan mutu pendidikan merupakan faktor yang sangat penting dilakukan bagi setiap individu untuk menjawab tantangan tersebut. Peningkatan mutu pendidikan untuk semua jenjang pendidikan merupakan prioritas dalam upaya mencerdaskan kehidupan bangsa. Pendidikan matematika yang diajarkan pada jalur sekolah merupakan pendidikan yang sangat mendasar dan diperlukan guna menguasai teknologi yang sementara ini berkembang.

Matematika sebagai salah satu ilmu dasar memegang peranan penting dalam mempercepat penguasaan ilmu dan teknologi. Hal ini disebabkan karena matematika merupakan sarana berpikir untuk menumbuhkembangkan cara berpikir logis, sistematis dan kritis. Ini berarti bahwa sampai batas tertentu matematika perlu dikuasai oleh setiap orang, khususnya di kalangan pendidikan baik penerapannya maupun pola pikirnya.

Dalam lampiran Permendikbud Nomor 21 Tahun 2016 dinyatakan bahwa standar Isi dikembangkan untuk menentukan kriteria ruang lingkup dan tingkat kompetensi yang sesuai dengan kompetensi lulusan yang dirumuskan pada Standar Kompetensi Lulusan, yakni sikap, pengetahuan, dan keterampilan. Karakteristik, kesesuaian, kecukupan, keluasan, dan kedalaman materi ditentukan sesuai dengan karakteristik kompetensi beserta proses pemerolehan kompetensi tersebut. Ketiga kompetensi tersebut memiliki proses pemerolehan yang berbeda. Kompetensi sikap dibentuk melalui aktivitas-aktivitas: menerima, menjalankan, menghargai, menghayati, dan mengamalkan. Kompetensi pengetahuan dimiliki melalui aktivitas-aktivitas: mengetahui, memahami, menerapkan, menganalisis, mengevaluasi, dan mencipta. Kompetensi keterampilan diperoleh melalui aktivitas-aktivitas: mengamati, menanya, mencoba, menalar, menyaji, dan mencipta.

Dalam Permendikbud Nomor 21 tahun 2016 adapun ruang lingkup materi matematika kelas $\mathrm{V}$ dalam pembelajaran matematika terdapat 3 aspek yaitu: (a) Bilangan bulat dan bilangan pecahan. (b) Geometri (sifat dan unsur) dan Pengukuran (satuan standar). (c) Statistika (pengumpulan dan penyajian data sederhana). Kompetensi yang diharapkan dalam pembelajaran matematika yang mencakup ketiga aspek tersebut diatas mencakup: (a) Menunjukkan sikap positif bermatematika: logis, kritis, cermat dan teliti, jujur, bertanggung jawab, dan tidak mudah menyerah dalam menyelesaikan masalah, sebagai wujud implementasi kebiasaan dalam inkuiri dan eksplorasi matematika. (b) Memiliki rasa ingin tahu, semangat belajar yang kontinu, rasa, percaya diri, dan ketertarikan pada matematika, yang terbentuk melalui pengalaman belajar mengidentifikasi 
kemiripan dan perbedaan berbagai sudut. (c) Menjelaskan pola bangun dalam kehidupan sehari-hari dan memberikan dugaan kelanjutannya berdasarkan pola berulang. (d) Memahami penjumlahan dan pengurangan bilangan bulat dan pecahan.

Mengelompokkan benda menurut bentuknya dan disertai justifikasi. (f) Menyelesaikan masalah aritmetika sehari-hari sebagai penerapan pemahaman atas efek penambahan dan pengurangan. (g) Menyadari objek dapat dipandang sebagai kesatuan dari bagian-bagiannya.

Memberikan interpretasi dari sebuah sajian informasi/data. (i) Menggunakan model konkret dan simbolik atau strategi lain dalam penyelesaian masalah sehari-hari.

Masalah klasik yang selalu dihadapi dan terus diupayakan pemecahannya dalam pelajaran matematika adalah respon peserta didik terhadap pelajaran matematika yang menganggap bahwa pelajaran matematika itu sulit. Banyak terdengar keluhan dari peserta didik bahwa pelajaran matematika tidak menarik, membosankan, menyeramkan, peserta didik tidak tertarik untuk belajar, hal ini disebabkan karena pelajaran matematika dirasakan sulit dan tidak tampak kaitannya dalam kehidupan sehari-hari. Diperlukan model pembelajaran metematika yang tepat sehingga anggapan peserta didik tentang pembelajaran matematika dapat diatasi. Proses berpikir manusia mengalami perkembangan, sehingga dalam melaksanakan pembelajaran khususnya pembelajaran matematika, diperlukan konsep tentang perkembangan intelektual peserta didik oleh guru. Unsur intelektual diperoleh dari konsep materi yang diajarkan, sedangkan unsur personal dan sosial individu diperoleh dari konsep dan penerapan dari materi yang diajarkan pada setiap mata pelajaran, salah satunya matematika.

Berdasarkan hasil observasi pada SDN 008 Camba-Camba, bahwa kemampuan peserta didik dalam menguasai materi pembelajaran

matematika

belum memuaskan, terbukti dari nilai ulangan peserta didik di kelas V SDN 008 CambaCamba, dari 29 orang peserta didik 65\% atau 18 peserta didik diantaranya memperoleh nilai yang masih dibawah nilai KKM. Rendahnya hasil belajar peserta didik, berdasarkan obsevasi diketahui, antara lain: (1) pembelajaran masih berpusat pada guru (teacher centered), (2) peserta didik kurang antusias dalam menjawab pertanyaan, (3) pertanyaan hanya dijawab oleh peserta didik yang pandai saja, (4) peserta didik mengalami kesulitan dalam mengemukakan pendapat atau gagasan untuk memecahkan suatu masalah dan, (5) guru belum maksimal dalam menerapkan model pembelajaran khususnya PBL.

Berdasarkan masalah yang ada di atas, perlu adanya penerapan model pembelajaran yang mampu membuat atau melibatkan peserta didik aktif, kreatif, menarik, inovasi dan menyenangkan dalam proses pembelajaran serta keteramapilan pemecahan masalah. Dengan adanya keterlibatan peserta didik secara langsung, maka dapat melatih peserta didik untuk membuat keputusan dari berbagai sudut pandang secara cermat, teliti, dan logis. Jika pelibatan peserta didik secara langsung pada setiap pembelajaran, maka akan terbentuk sumber daya manusia yang cerdas dalam berpikir dan kritis dalam menyelesaikan masalah. Oleh karena itu proses pembelajaran di sekolah termasuk dalam pembelajaran matematika sebaiknya melatih peserta didik untuk menggali kemampuan dan keterampilan dalam mencari, mengolah, dan menilai berbagai informasi secara kritis. Hal ini menjadi tugas pendidik untuk menghadirkan suasana belajar yang mengaktifkan peserta didik.

Pembelajaran matematika di Sekolah Dasar juga harus disesuaikan dengan pola perkembangan (tahapan) kognitif anak. Jean Piaget menyatakan bahwa anak-anak Sekolah Dasar (7-11 tahun) bearada pada tahap 
operasional konkret sehingga secara natural cara belajar yang terbaik bagi anak adalah secara nyata dengan melihat, merasakan, dan melakukan secara langsung. Oleh karena itu, guru hendaknya mengembangkan pembelajaran yang mengandung unsur yang menyenangkan, memnungkinkan peserta didik berpindah atau bergerak dan bekerja dalam kelompok, serta memberikan kesempatan kepada peserta didik untuk terlibat langsung dalam pembelajaran.

Dengan model problem based learning dapat membantu pendidik dalam memberikan informasi sebanyak-banyaknya kepada peserta didik, dapat membantu peserta didik untuk kemampuan berpikir, pemecahan masalah dan keterampilan intelektual, belajar tentang berbagi peran melalui pelibatan mereka dalam pengalaman nyata, dan menjadi pembelajar yang otonom dan mandiri.

Ali Mudlofir (2016), Strategi problem based learning (Problem Based Learning) merupakan salah satu model pembelajaran inovatif yang dapat memberikan kondisi belajar aktif kepada peserta didik. Pengertian problem based learning adalah suatu model pembelajaran yang melibatkan peserta didik untuk memecahkan suatu masalah melalui tahap-tahap metode ilmiah sehingga peserta didik dapat mempelajari pengetahuan yang berhubungan dengan maslah tersebut dan sekaligus memiliki keterampilan untuk memecahkan masalah.

Menurut Arends (Ali Mudlofir, 2016), Model pembelajaran problem based learning merupakan suatu pendekatan pembelajaran di mana peserta didik mengerjakan permasalahan yang autentik dengan maksud untuk menyusun pengetahuan mereka sendiri, mengembangkan inkuiri dan keterampilan berpikir tingkat lebih tinggi, mengembangkan kemandirian dan percaya diri.

Wina Sanjaya (Trianto, 2017), menyatakan pembelajaran berbasis maslah (problem based learning) dapat diartikan sebagai rangkaian aktivitas pembelajaran yang menekankan kepada proses penyelesaian masalah yang dihadapi secara alamiah.

Berdasarkan uraian diatas, dapat disimpulkan bahwa model pembelajaran problem based learning merupakan model pembelajaran yang di dalamnya terdapat rangkaian aktivitas yang dilakukan baik secara kelompok atau secaraa individual dalam memecahkan suatu permasalan yang berkaitan dengan dunia nyata yang menuntut peserta didik untuk berpikir, berkomunikasi, mencari dan meyelesaikan masalah dengan berpikir secara ilmiah.

Problem based learning merupakan rangkaian aktivitas pembelajaran, artinya dalam implementasi ada sejumlah kegiatan yang harus dilakukan peserta didik. Problem based learning tidak mengharapkan peserta didik yang hanya sekedar mendengarkan, mencatat, kemudian menghafasl metri pelajaran, akan tetapi melalui problem based learning peserta didik aktif berfikir, berkomunikasi, mencari dan mengolah data, dan akhirnya menyimpulkan.

Aktivitas pembelajaran diarahkan untuk menyelesaikan masalah. Problem based learning Menempatkan masalah sebagai kata kunci dari proses pembelajaran, Artinya tanpa masalah maka tidak mungkin ada proses pembelajaran. Pemecahan masalah dilakukan dengan menggunakan pendekatan berpikir secara ilmiah. Berpikir dengan menggunakan metode ilmiah adalah proses berfikir deduktif dan induktif.

Berdasarkan uraian permasalahan tersebut, maka penleitianini bertujuan untuk mengetahui gambaran penerapan model pembelajaran problem based learning dalam pembelajaran matematika pada SDN 008 Camba-camba Kabupaten Polewali Mandar, dan gambaran hasil belajar matematika peserta didik SDN 008 Camba-camba sebelum dan setelah penerapan model 
pembelajaran problem based learning, serta pengaruh penerapan model problem based learning terhadap hasil belajar matematika peserta didik kelas V SDN 008 CambaCamba.

\section{METODE}

Jenis penelitian ini adalah penelitian kuantitatif dengan metode pre-experimental designs. Lokasi penelitian ini bertempat di SDN 008 Camba-camba Kabupaten Polewali Mandar.Pada penelitian terdapat dua variabel yaitu variabel bebas (independent variable) dan variabel terikat (dependent variable). Adapun variabel bebas dalam penelitian ini yaitu model pembelajaran problem based learning. sedangkan variabel terikat yaitu hasil belajar matematika

Adapun rancangan yang digunakan dalam penelitian ini adalah one-group pretestposttest design, desain ini dapat digambarkan sebagai berikut:

$\begin{array}{lll}\mathbf{O}_{1} & \mathrm{X} & \mathrm{O}_{2}\end{array}$

Sumber: Sugiyono (2016:112)

Keterangan:

$\mathrm{O}_{1}$ : Nilai pretest (nilai matematika peserta didik sebelum diajar dengan model pembelajaran problem based learning).

$\mathrm{X}$ : Perlakuan (menerapkan model pembelajaran problem based learning).

$\mathrm{O}_{2}$ : Nilai posttest (nilai matematika peserta didik setelah diajarkan dengan model pembelajaran problem based learning).

Populasi dalam penelitian ini adalah seluruh peserta didik Skelas V SDN 008 Camba-Camba Kabupaten Polewali Mandar yang berjumlah 29 orang dengan sampel penelitian ini adalah seluruh peserta didik kelas V SDN Camba-camba yang berjumlah 29 peserta didik.

Teknik pengumpulan data penelitian yang digunakan yaitu observasi dan tes hasil belajar matematika.

1. Observasi digunakan untuk mengukur atau menilai proses belajar, yaitu gambaran pelaksanaan penggunaan Model pembelajaran problem based learning dan tingkah laku peserta didik pada saat pembelajaran.

2. Tes hasil belajar matematika ditujukan untuk memperoleh informasi langsung mengenai hasil belajar matematika peserta didik. Tes ini terdiri atas pretest dan posttest.

Instrumen penelitian yang digunakan dalam penelitian ini terdiri atas dua yaitu lembar observasi dan tes hasil belajar yang digunakan oleh peneliti sebagai alat bantu dalam proses pengumpulan data penelitian.

1. Lembar observasi digunakan untuk mengetahui seberapa baik keterlaksanaan model pembelajaran problem based learning. Selain menggunakan lembar observasi, tes juga menjadi instrumen dalam penelitian ini

2. Soal tes, tes digunakan untuk memperoleh informasi mengenai hasil belajar matematika peserta didik kelas V SDN 008 Camba-camba.

Data hasil penelitian dianalisis dengan menggunakan SPSS dengan teknik analisis data dilakukan melalui Uji Asumsi Klasik dan Analisis Regresi Sederhana.

Uji hipotesis pada penelitian ini menggunakan uji dua pihak. Uji dua pihak digunakan bila hipotesis nol $\left(\mathrm{H}_{\mathrm{o}}{ }^{\prime}\right.$ berbunyi "sama dengan" dan hipotesis alternatifnya (Ha) berbunyi "tidak sama dengan" $\left(\mathrm{H}_{\mathrm{o}}=;{ }_{\mathrm{a}}\right.$ $\neq)$.

\begin{tabular}{llll}
\hline Kelompok & \multicolumn{2}{l}{ Sig. (2-tailed) } & Kesimpulan \\
& Pretest & Postest & \\
Eksperimen & 0.067 & 0.101 & Normal \\
\hline
\end{tabular}

Selain itu penelitian ini juga menggunakan uji-t hipotesis dengan menggunakan rumus sebagai berikut:

$$
\mathrm{t}_{\text {hit }}=\frac{x_{1}-x_{2}}{S_{g a b} \cdot \sqrt{\frac{1}{n_{1}}+\frac{1}{n_{2}}}}
$$

Dimana : 


$$
s_{g a b}=\sqrt{\frac{\left(n_{1}-1\right) s_{1}^{2}+\left(n_{2}-1\right) s_{2}^{2}}{n_{1}+n_{2}-2}}
$$

Keterangan :

$\underline{\mathrm{x}}_{1}:$ Rata-rata post-test

$\underline{\mathrm{x}}_{2}:$ Rata-rata pre-test

$\mathrm{n}_{1}$ : Jumlah subyek post-test

$\mathrm{n}_{2}$ : jumlah subyek pre-test

$\mathrm{s}_{1}^{2}:$ Standar deviasi post-test

$\mathrm{s}_{2}^{2}:$ Standar deviasi pre-test

$\mathrm{s}_{\mathrm{gab}}:$ simpangan baku

Dengan kriteria pengujinya adalah terima $H_{0}$ jika $\mathrm{t}_{\text {tabel }}>\mathrm{t}_{\text {hitung }}$ dimana $\mathrm{t}_{\text {tabel }}$ didapat dari daftar distribusi $\mathrm{t}$ dengan $d k=\left(n_{1}+n_{2}-2\right)$ dan tolak $H_{0}$ untuk harga $t$ yang lain.

\section{HASIL DAN DISKUSI}

Gambaran Penerapan Model Pembelajaran Problem Based Learning Dalam Pembelajaran Matematika Peserta Didik SD Kelas V

Hasil observasi aktivitas guru pada pertemuan pertama hingga ketiga menunjukkan bahwa dari tahap penerapan model pembelajaran problem based learning diobservasi oleh guru kelas $\mathrm{V}$ itu sendiri. Hal yang diamati berupa kegiatan inti berdasarkan langkah-langkah keterlaksanaan pembelajaran yang tercantum di RPP. Keterlaksanaan setiap langkah-langkah yang diamati oleh observer diberi tanda cek list pada jawaban ya atau tidak.

Berdasarkan hasil pengamatan observer, aktivitas guru dalam pembelajaran matematika menggunakan model problem based learning Secara umum langkah-langkah kegiatan pada setiap pertemuan dilaksanakan dengan baik oleh guru dan pada setiap pertemuan bisa dikatakan berada pada kategori yang baik.

Hasil observasi aktivitas belajar peserta didik pada pertemuan pertama hingga ketiga menunjukkan tahap penerapan model pembelajaran problem based learning yang diobservasi adalah peserta didik kelas V. Hal yang diamati berupa kegiatan yang dilakukan peserta didik sesuai dengan langkah-langkah pembelajaran model model pembelajaran problem based learning dan yang tercantum pada rencana pelaksanaan pembelajaran (RPP). Setiap langkah yang diamati oleh observer diberi tanda ceklist dan kemudian dianalisis dengan memberi nilai ya atau tidak.

Berdasarkan hasil pengamatan yang dilakukan observer, peserta didik dalam pembelajaran menggunakan model pembelajaran problem based learning pada setiap pertemuan mengalami perubahan yang lebih baik, antusias peserta didik dalam setiap pertemuan berbeda-beda, pada pertemuan pertama peserta didik kurang bersungguhsungguh, pertemuan kedua situasi kelas lebih baik, dan pertemuan terakhir setiap peserta didik memahami setiap instruksi guru.

\section{Gambaran Hasil Pembelajaran Matematika Sebelum dan Setelah Penerapan Model Pembelajaran Problem Based Learning \\ Berdasarkan pengkategorian hasil} belajar peserta didik kelas V SDN 008 Camba-Camba sebelum diajar dengan menggunakan model pembelajaran problem based learning, maka dapat diketahui bahwa hasil belajar peserta didik pada kategori sangat rendah dengan persentasi 55,17\% terdapat 16 orang peserta didik, kategori rendah dengan persentasi $20,68 \%$ terdapat 6 peserta didik, kategori sedang dengan persentase $24,13 \%$ terdapat 7 Peserta Didik dan tidak terdapat peserta didik pada kategori tinggi dan sangat tinggi. Jadi berdasarkan persentasi diatas maka dapat dikategorikan bahwa sebagian besar besar hasil belajar peserta didik kelas V SDN 008 Camba-Camba sebelum diajar dengan model pembelajarn berbasis masalah berada pada kategori sangat rendah.

Berdasarkan pengkategorian hasil belajar peserta didik kelas V SDN 008 Camba-Camba sebelum diajar dengan menggunakan model pembelajaran problem based learning, maka dapat diketahui bahwa hasil belajar peserta didik pada kategori 
sangat rendah dengan persentasi $10,34 \%$ terdapat 3 orang peserta didik, kategori rendah dengan persentasi $17,24 \%$ terdapat 5 peserta didik, kategori sedang dengan persentase $27,58 \%$ terdapat 8 Peserta Didik, kategori tinggi dengan persentase 20,68\% terdapat 6 peserta didik dan kategori sangat tinggi dengan persentase $24,13 \%$ terdapat 7 peserta didik. Jadi berdasarkan persentasi diatas maka dapat dikategorikan bahwa sebagian besar hasil belajar peserta didik kelas V SDN 008 Camba-Camba setelah diajar dengan model pembelajarn berbasis masalah berada pada kategori Sedang.

\section{Pengaruh Penerapan Model Pembelajaran Problem Based Learning Terhadap Hasil Belajar Matematika Peserta Didik SD Kelas V}

Hipotesis penelitian ini mengatakan bahwa "terdapat pengaruh penerapan model pembelajaran problem based learning terhadap hasil belajar matematika peserta didik kelas V SDN 008 Camba-Camba Kabupaten Polewali Mandar.

Uji hipotesis dilakukan setelah uji prasyarat analisis yaitu dengan melakukan uji normalitas. Dengan menggunakan uji $t$ dengan kriteria pengujinya adalah terima $H_{0}$ jika Sig $>\alpha=0,05$ dan tolak $H_{0}$ untuk harga yang lain. Uji-t dibantu program SPSS 25 menggunakan teknik independent sample test. Teknik ini merupakan uji beda dua sampel berpasangan dimana sampel berpasangan merupakan subjek yang sama namun mengalami perlakuan yang berbeda. Menu yang digunakan adalah analyze-compare meansindependent sample t-tes. Untuk mengetahui apakah $\mathrm{H}_{1}$ dan $\mathrm{H}_{0}$ diterima atau ditolak adalah dengan melihat nilai kolom sig. (2tailed). Dalam uji dua pihak berlaku ketentuan sebagai berikut:

$\mathrm{H}_{0}$ : Rata-rata nilai hasil belajar peserta didik sebelum penerapan model problem based learning (problem based learning) sama dengan nilai rata-rata hasil belajar peserta didik setelah penerapan model problem based learning (problem based learning).

$\mathrm{H}_{1}$ : Rata-rata nilai hasil belajar peserta didik sebelum penerapan model problem based learning (problem based learning) tidak sama dengan nilai rata-rata hasil belajar peserta didik setelah penerapan model problem based learning (problem based learning).

Pengambilan keputusan didasarkan pada hasil uji-t yang diperoleh, yitu:

1) Jika nilai signifikansi atau sig. sig. (2tailed) $>\alpha(0,05)$, maka $\mathrm{H}_{0}$ diterima dan $\mathrm{H}_{1}$ ditolak.

2) Jika nilai signifikansi atau sig. sig. (2tailed $)<\alpha(0,05)$, maka $\mathrm{H}_{0}$ ditolak dan $\mathrm{H}_{1}$ diterima.

Berdasarkan Uji $t$ yang dilakukan terlihat bahwa nilai signifikansi $<0,05$ yaitu $0,000<0,05$ sehingga dapat disimpulkan bahwa $\mathrm{H}_{0}$ ditolak dan $\mathrm{H}_{1}$ diterima, artinya terdapat pengaruh penerapan model pembelajaran problem based learning terhadap hasil belajar matematika peserta didik kelas $\mathrm{V}$ SDN 008 Camba-Camba Kabupaten Polewali Mandar.

Penerapan model pembelajaran problem based learning secara umum dan langkahlangkah kegiatan pada setiap pertemuan dilaksanakan dengan baik oleh guru, terlihat dari konsistennya hasil pengamatan dari pertemuan pertama hingga pertemuan ketiga. Pada pertemuan pertama, penerapan model pembelajaran problem based learning mendapat kategori penilaian baik, begitu juga dengan pertemuan kedua, dan pada pertemuan ketiga mendapat perolehan kategori sangat baik. Konsistensi kategori penilaian baik ini terjadi karena adanya refleksi yang dilakukan oleh peneliti pada setiap akhir pembelajaran. Sesuai dengan pendapat Denielson (2007) "agar produktif refleksi atas pembelajaran harus sistematis dan analisis. Sebab itu, untuk meningkatkan keterampilan dalam refleksi seseorang harus belajar bagaimana menganalisis semua keputusan yang dibuat 
dalam merancang pembelajaran dan pengaturan yang dibuat sepanjang pembelajaran itu sendiri".

Dalam penerapan model pembelajaran problem based learning, guru menyampaikan tujuan pembelajaran yang akan dipelajari hari itu, kemudian guru membentuk peserta didik menjadi lima kelompok, tiap kelompok terdiri dari 5 orang peserta didik. Pembelajaran diawali dengan pemecahan masalah yang ada di sekitar peserta didik dan berbasis pada pengalaman yang telah dimiliki peserta didik. Pada proses pembelajaran terdapat interaksi yang kuat antara peserta didik yang satu dengan peserta didik yang lain. Menurut Runtukahu dan Kandou (2014) "komunikasi merupakan bagian yang tidak terpisahkan dengan belajar. Anak dari semua tingkatan belajar harus belajar bagaimana menggunakan kata-kata matematika secara lisan sebelum mereka menyajikannya dengan tanda simbol. Anak berkesulitan belajar matematika dianjurkan untuk berbicara apa yang dipikirkannya".

Pembagian tiap kelompok berdasarkan kemampuan peserta didik, dengan pertimbangan jika peserta didik mempunyai kemampuan yang berbeda dimasukkan dalam kelompok yang sama maka peserta didik yang berkemampuan sedang dan rendah akan termotivasi untuk belajar dan peserta didik yang berkemampuan lebih akan mampu menjadi tutor bagi temannya yang lain. Menurut Suciati,dkk (2007) "dalam kegiatan ini tutorial peserta didik lebih pandai membantu peserta didik yang menghadapi kesulitan dalam memahami materi pelajaran". Dengan pembelajaran ini peserta didik membantu teman yang belum paham, sehingga akan terjadi kegiatan belajar yang aktif, komunikatif dan menyenangkan.

Pembelajaran dengan $r$ model
pembelajaran problem based learning pada
pertemuan pertama peserta didik sudah
mampu menemukan masalah dan
bekerjasama dalam kelompok dan sesuai

dengan langkah-langkah pembelajaran yang diterapkan. Peserta didik tampil didepan kelas dan mampu berbicara didepan temantemannya untuk mewakili kelompoknya menjelaskan hasil jawaban kelompok. Begitu pula dengan pertemuan kedua, dan ketiga. Pelaksanaan pembelajaran pada setiap pertemuan telah dilaksanakan dengan baik, karena dasarnya peserta didik lebih lebih aktif dan senang belajar dengan menggunakan model ini. Mereka merasa bahwa mereka diberikan kesempatakan untuk mengeluarkan ide-ide yang mereka miliki dalam kaitannya dengan interaksi peserta didik dalam proses belajar untuk mengoptimalkan jawaban mereka. Selain itu mereka juga menjalin kekompakan bersama temannya. Hal tersebut diatas sesuai dengan pendapat yang dikemukakan oleh Suharjo (2006) Pembelajaran merupakan sesuatu yang kompleks. Pembelajaran tidak hanya sekedar menyampaikan pesan kepada peserta didik, akan tetapi merupakan aktivitas profesional yang menuntut guru untuk dapat menggunakan keterampilan dasar mengajar secara terpadu, serta menciptakan sistem lingkungan yang memungkinkan peserta didik dapat belajar secara efektif dan efisien untuk mendapatkan hasil yang maksimal.

Berkat kerja sama yang baik antara guru dengan peserta didik, peserta didik dengan peserta didik itu sendiri,sehingga pelaksanaan pembelajaran dengan menggunakan model pembelajaran problem based learning berjalan sesuai yang diharapkan dan hasil belajarnya pun menjadi lebih baik. Perubahan hasil belajar dapat ditandai dengan perubahan tingkah laku dan tingginya hasil belajar yang diperolah peserta didik. Hal ini sesuai dengan pendapat Sudjana (1989) menjelaskan bahwa hasil belajar adalah kemampuan-kemampuan yang dimiliki peserta didik setelah ia menerima pengalaman belajarnya. Pengalaman belajar tersebut dapat diperoleh di sekolah, rumah, dan masyarakat sekitar. Hasil belajar yang dibentuk diharapkan 
menjadi perubahan tingkah laku kearah yang lebih baik. Hal tersebut membuktikan bahwa terjadi peningkatan hasil belajar peserta didik yang ditandai dengan tingginya hasil belajar secara klasikal.

Dengan demikian, penerapan model pembelajaran problem based learning memungkinkan untuk dijadikan sebagai salah satu model pembelajaran dalam peningkatan hasil belajar peserta didik terutama dalam materi pembelajaran matematika yang merujuk pada ada perbedaan hasil belajar peserta didik kelas V SDN 008 CambaCamba Kabupaten Polewali Mandar.

Berdasarkan hasil penelitian yang telah dilaksanakan dapat diketahui bahwa terdapat pengaruh hasil belajar peserta didik. Data penelitian ini merupakan data penilaian pretest dan posttest. Sebelum penerapan model pembelajaran problem based learning dilaksanakan pretest dan setelah menggunakan model pembelajaran tersebut dilaksanakan penilaian akhir yaitu posttest. Data hasil penilitian ini menunjukkan data hasil nilai rata-rata pada pretest berada pada kategori rendah. Berbeda dengan nilai data hasil nilai posttest nilai rata-rata berada pada kategori tinggi.

Hasil ini menunjukkan bahwa penerapan model pembelajaran problem based learning berpengaruh terhadap hasil belajar Matematika peserta didik. Hal tersebut diatas sesuai dengan pendapat Susanto (2015) Secara umum, tujuan pembelajaran matematika di SD adalah agar mampu terampil dalam mengembangkan kemampuan berpikir dan bernalar yang berhubungan dengan masalah matematika.

Nilai rata-rata pada peserta didik pada saat postest lebih tinggi karena kemampuan peserta didik setelah diberikan perlakuan memahami materi lebih baik jika dibandingkan dengan sebelum diterapkannya model pembelajaran problem based learning. Dengan menggunakan model pembelajaran problem based learning peserta didik lebih memahami materi yang dipelajari karena pembelajaran berlangsung dengan situasi yang menyenangkan dan bermakna bagi peserta didik.

Pembelajaran berlangsung dengan tahapan problem based learning dilaksanakan oleh guru dengan baik, guru dalam pembelajaran hanya bertindak sebagai fasilitator dan memberi kesempatan kepada peserta didik untuk lebih aktif dalam memecahkan masalah dan mengembangkan pengetahuannya serta lebih aktif bekerja sama dengan teman kelompoknya. Pelaksanaan pembelajaran ini dilakukan oleh guru dengan baik. Sesuai dengan rencana pelaksanaan pembelajaran yang dilakukan setiap hari.

Hasil penelitian menunjukkan nilai yang lebih tinggi pada nilai postest peserta didik karena kemampuan peserta didik dalam memahami materi yang dipelajari. Dengan demikian, dengan penerapan model pembelajaran problem based learning tersebut peserta didik dapat dengan mudah memahami materi pelajaran yang disampaikan oleh guru dan dapat saling membantu dengan temannya karena proses pembelajaran dilakukan secara berkelompok. selain itu peserta didik tedorong untuk bertanya yang dipicu dari permasalahan yang didapatkan dari hasil pengamatannya.

Untuk mengetahui penerapan model pembelajaran problem based learning maka dilakukan uji hipotesis. Sebelum melakukan uji hipotesis dilakukan uji normalitas nilai pretest dan postest untuk mengetahui apakah data tersebut berdistribusi normal atau tidak. Berdasarkan hasil analisis uji normalitas dengan menggunakan bantuan SPSS versi 25 kolmogrov-smirnov diperoleh data sign (2 tailed) > 0,05 .itu berarti bahwa data berdistribusi normal.

Selanjutnya dilakukan uji hipotesis dengan menggunakan uji Paired Sample tTest. bahwa hasil uji t menunjukkan nilai sign (2 tailed) sebesar $0,000<0,05$.Dengan demikian $\mathrm{H}_{0}$ ditolak dan $\mathrm{H}_{1}$ diterima atau 
dapat dinyatakan bahwa terdapat pengaruh penerapan model pembelajaran problem based learning terhadap hasil belajar matematika kelas V SDN 008 Camba-Camba Kabupaten Polewali Mandar.

Menurut Nana Sudjana (2010), hasil belajar yang dicapai peserta didik dipengaruhi oleh dua faktor utama yakni fakor dari dalam diri peserta didik itu dan faktor yang datang dari luar diri peserta didik atau faktor lingkungan. Faktor yang datang dari dalam diri peserta didik terutama kemampuan yang dimilikinya. Faktor kemampuan peserta didik besar sekali pengaruhnya terhadap hasil belajar yang dicapai. Di samping faktor kemampuan yang dimiliki peserta didik, juga ada faktor lain seperti motivasi belajar, minat dan perhatian, sikap dan kebiasaan belajar, ketekunan, sosial ekonomi, faktor fisik dan psikis. Adanya pengaruh dari dalam diri peserta didik merupakan hal yang logis dan wajar, sebab hakikat perbuatan belajar adalah perubahan tingkah laku individu yang diniati dan disadarinya.

Dari hasil pelaksanaan dan tes yang dilakukan kemudian di deskripsikan dalam analisis data, dihasilkan pengaruh yang signifikan terhadap penerapan model pembelajaran problem based learning di SDN 008 Camba-Camba Kabupaten Polewali Mandar. Pengaruh yang dihasilkan ini tidak terlepas dari penerapan pembelajaran itu sendiri yang berjalan dengan efektif. Hal tersebut juga disebabkan pembelajaran lebih menyenangkan karena pembelajaran di awali dengan menggunakan masalah kontekstual, yang dimana masalah kontesktual yang diangkat sebagai topik awal pembelajaran merupakan masalah sederhana yang dikenali oleh peserta didik. Selain itu juga terjadi diskusi dengan mengemukakan ide-ide para peserta didik di tiap kelompoknya, hal tersebut karena adanya interaksi antara teman kelompoknya. Sesuai dengan pengertian dari model pembelajaran Problem based learning yang dikemukakan oleh Mudlofir (2016), pengertian problem based learning adalah suatu model pembelajaran yang melibatkan peserta didik untuk memecahkan suatu masalah melalui tahap-tahap metode ilmiah sehingga peserta didik dapat mempelajari pengetahuan yang berhubungan dengan masalah tersebut dan sekaligus memiliki keterampilan untuk memecahkan masalah. Hal ini didukung dengan penilitian sebelumnya yang dilakukan oleh Rifka Anisaunnafi'ah (2015), bahwa terdapat Pengaruh Model Problem Based Learning terhadap Motivasi Belajar Ilmu Pengetahuan Sosial Pada Peserta didik Kelas IV SD Negeri Grojogan Tamanan Banguntapan Bantul. Penelitian serupa juga dilakukan Endang Selfiana (2015), tentang Pengaruh Model Pembelajaran Problem Based Learning (PBL) terhadap Hasil Belajar Peserta didik Pada Mata Pelajaran IPA Kelas V di SD Islam Al-azhar 34 Makassar menyatakan bahwa terdapat perbedaan hasil belajar IPA peserta didik antara peserta didik yang diajar dengan model pembelajaran problem based learning (PBL) dengan hasil belajar peserta didik yang tidak diajar dengan menggunakan model pembelajaran problem based learning (PBL). Hal ini menunjukkan bahwa penggunaan model pembelajaran problem based learning (PBL) memberikan pengaruh yang lebih besar dan positif terhadap hasil belajar IPA peserta didik. Oleh karena itu, model pembelajaran problem based learning ini diterapkan, maka dapat membantu pendidik memberikan informasi sebanyak-banyaknya kepada peseta didik, dapat membantu peserta didik untuk mengembangkan kemampuan berfikir, pemacahan masalah dan keterampilan intelektual, belajar tentang barbagi peran melalu pelibatan mereka dalam pengalaman nyata atau simulasi, dan menjadi pembelajar yang otonom dan mandiri. Sehingga dapat dikemukakan bahwa dalam penelitian ini terdapat pengaruh yang signifikan penerapan model pembelajaran problem based learning terhadap hasil belajar 
matematika peserta didik kelas V SDN 008 Caba-Camba Kabupaten Polewali Mandar.

\section{KESIMPULAN}

Dari hasil penelitian yang dilakukan pada peserta didik kelas V SDN 008 CambaCamba Kabupaten Polewali Mandar diperoleh kesimpulan bahwa, (1) hasil penerapan model pembelajaran problem based learning pada peserta didik kelas V SDN 008 Camba-Camba Kabupaten Polewali Mandar berjalan secara efektif; (2) hasil belajar matematika peserta didik kelas V SDN 008 Camba-Camba Kabupaten Polewali Mandar sebelum penerapan model pembelajaran problem based learning berada pada kategori rendah dan gambaran hasil belajar matematika peserta didik kelas V SDN 008 Camba-Camba Kabupaten Polewali Mandar sebelum penerapan model pembelajaran problem based learning berada pada kategori sedang, (3) terdapat pengaruh penerapan model pembelajaran problem based learning terhadap hasil belajar matematika peserta didik kelas V SDN 008 Camba-Camba Kabupaten Polewali Mandar. Oleh karena itu, untuk meningkatkan hasil belajar IPA peserta didik, maka model pembelajaran problem based learning sangat penting untuk diterapkan.

\section{REFERENSI}

Ahmadi, Abu \& Supriyono,Widodo. (2013). Psikologi Belajar. Jakarta: PT. Rieneka Cipta.

Arikunto, Suharsimi \& Safruddin, Cepi. (2007). Evaluasi Program Pendidikan Pedoman Teoritis Bagi Praktisi Pendidikan. Cet.II; Jakarta: Bumi Aksara.

Arikunto, Suharsimi. (2010). Dasar-Dasar Evaluasi Pendidikan. Cet. Ke-I. Jakarta: Bumi Aksara, 2010.

-----. (2013). Prosedur Penelitian: Suatu Pendekatan Praktis. Cet Ke-XV. Jakarta: Rieneka Cipta.
Azwar, Saifuddin. (2008). Reliabilitas dan Validitas. Yogyakarta: Pustaka Pelajar Dalyono, Muhammad. (2007). Psikologi Pendidikan. Jakarta: PT. Rieneka Cipta

Depdiknas, Pedoman Umum Sistem Pengujian Hasil Belajar (www.google.com)

Haling, Abd. (2007). Belajar dan Pembelajaran.

Makassar: Badan Penerbit Universitas Negeri Makassar.

Hasan, M. Iqbal. (2015). Pokok-pokok Materi Statistik 2 (Statistik Inferensial). Cet. VIII; Jakarta:PT Bumi Aksara.

Huda, Miftahul. (2015). Model-Model Pengajaran dan Pembelajaran.

Yogyakarta: Pustaka Pelajar.

Ibnu, Trianto. (2017). Desain pengembangan Pembelajaran Tematik. Jakarta: Prenadamedia.

Nursalam. (2013). Strategi Pembelajaran Matematika: Teori dan Aplikasi Bagi Mahasiswa PGMI. Makassar: Alauddin University Press.

Pedoman Penulisan Tesis Program Pascasarjana Universitas Negeri Makassar. (2018). Makassar: Badan Penerbit UNM.

Rusman. (2016). Model-Model Pembelajaran: Mengembangkan Profesionalisme Guru Ed.

2. Cet Ke-VI; Jakarta: Rajawali Pers.

-----. (2017). Belajar dan Pembelajaran: Berorientasi Standar Proses Pendidikan. Jakarta: Kencana.

Sagala, Syaiful. (2005). Konsep dan Makna Pembelajaran. Bandung: Alfabeta.

Sitiatava, Rizema Putra. (2013). Desain Belajar Mengajar Kreatif Berbasis Sains. Yogyakarta: Diva Press.

Sugiyono. (2010). Metode Penelitian Pendidikan (Pendekatan Kuantitatif, kualitatif, dan $R \& D)$. Cet. XI; Bandung:Alfabeta.

(2013). Metode Penelitian Pendidikan (Pendekatan Kuantitatif, kualitatif, dan $R \& D)$. Cet Ke-XXIII: Bandung: Alfabeta.

Tiro, M. A. (2008). Dasar-dasar Statistika. Cet. III; Makassar: Andira Publisher. 
Wijaya, Ariyadi. (2012). Pendekatan

Matematika Realistik: Suatu Alternatif

Pendekatan Pembelajaran Matematika.

Yogyakarta: Graha Ilmu. 